\title{
An Application of Flipped Classroom in Mathematics Teacher Education Programme
}

\author{
https://doi.org/10.3991/ijim.v13i03.10207 \\ Khoerul Umam \\ Universitas Negeri Malang, Malang, Indonesia \\ Universitas Muhammadiyah Prof. Dr. Hamka, Jakarta, Indonesia \\ Toto Nusantara ${ }^{\bowtie}$, I Nengah Parta, Erry Hidayanto \\ Universitas Negeri Malang, Malang, Indonesia \\ toto.nusantara.fmipa@um.ac.id \\ Herri Mulyono \\ Universitas Muhammadiyah Prof Dr Hamka, Jakarta, Indonesia
}

\begin{abstract}
A body of literature has suggested the benefits of flipped classrooms in mathematics learning at university. However, there is still a lack of evidence regarding the benefits in the context of mathematics teacher education programme. This study aimed to examine the effectiveness of a flipped classroom application in a mathematics teacher education programme at a private university in Indonesia. A total of thirty-one pre-service teachers participated in the study. Multiple data collection methods were employed including observation, written journals and tests. The data were then analysed both quantitatively and qualitatively. The findings showed that flipped classroom promotes independent learning, with the type of classroom encouraging students to work together with other peers and improved learning awareness. However, some challenges were highlighted in flipped classroom application such as technical issues, editing recording skills, and it was time consuming. Recommendations are offered in reference with the findings.
\end{abstract}

Keywords-Flipped classroom, mathematical modelling, teacher education, pre-service teacher

\section{Introduction}

Recently, flipped classroom has become increasingly popular in teaching and learning classrooms. In Journal of Interactive Mobile Technologies particularly, we have identified at least three studies examining the application of flipped classroom learning in educational classroom settings, such as Martínez and Garaizar [1] and Ng and Baharom [2]. A body of literature has been suggested that flipped classroom instruction offered benefits as well as an alternative method to the traditional learning environment, where learning started mainly from the classroom [3]. For example, White, McCollum, Bradley Roy, Yoon, Martindale, and Worden [2], state that the 
flipped classroom-learning model provides students with opportunities to take control of their own learning process, constructing knowledge before the classroom activity. Such a control, according to White at al., may help the students to focus and sharpen their learning activities through high-order learning exercises [4]. In addition, flipped classroom learning promotes both students' individual and collaborative learning with their peers as teachers have prepared and organised all learning materials, including podcasts of the class sessions, as well as other cases or problems with set answers that students can access online apart from their classroom sessions.

In particular, the application of flipped classroom within the field of mathematics learning at school as well as university classrooms has also attracted attention from practitioners as well as researchers, among others, Muir and Greiger [3] and Wasserman, Quint, Norris and Carr [5]. Muir and Geiger conducted a study to examine the application of the flipped classroom in a grade 10 mathematics learning classroom. They revealed that the flipped classroom offered the flexibility to cater to the wide range of students' needs in learning mathematics, potentially optimising the available time to improve students' understanding of mathematical concepts. The flexibility assistance as offered by the application of flipped classroom included video resources, explanation of particular concepts, exercises, and other types of tutorial materials. This kind of assistance in turn enabled the students to take more responsibility for their own learning, thus improve their autonomy in mathematics learning.

Wasserman et al. [5] examined the use of flipped classroom in teaching Calculus III within the context of higher education and found that it increased students' communication skills during the class session and more importantly, such an application improved their mathematical performance. The central argument for the improvement relied upon students' active discussion with their peers during the classroom activities, through which students were encouraged to exchange and share their understanding with their peers regarding the material they had already learned. In other words, flipped classroom learning benefits the students in that it provides personalised learning experiences. Moreover, it may facilitate the students to not only improve their understanding but also motivate them to achieve their learning competences [6].

In the current study, we adopted a flipped classroom design to facilitate preservice teachers' learning of mathematical modelling. Specifically, the application of flipped classroom aimed to facilitate two main activities:

- To provide opportunities for pre-service teachers to learn and practice mathematics modelling within a flipped environment via video lectures material

- To promote independent and collaborative learning among the pre-service teachers.

The use of flipped classroom teaching model in learning mathematics is relatively new. Nonetheless, reflection of the flipped classroom activity has a very important role in supporting the development and improvement of the quality of learning mathematical modelling [7], [8]. Reflective teaching provides meaningful opportunities to collect information about what is happening in the classroom [9], so that we can identify 
successful activities. To understand the effectiveness of the flipped classroom, researchers used two main instruments, namely a teaching journal and students' responses. The teaching journal was examined with our collaborators during the entire class, while students' responses were gathered using a survey with questions regarding learning material, video lectures, and classroom activities scored on a Likert scale. This reflective teaching activity has the potential to influence and promote future success in improving class practice [10].

\section{Theoretical Framework}

\subsection{Flipped classroom instruction in the mathematics classroom}

Flipped classroom (henceforth, FC) instruction offers an alternative to traditional learning, where learning started from the class [1] [9] [10]. FC provides students an opportunity to be more proficient in the fundamental knowledge before class [13], [14], so that class activities can be concentrated to refine their understanding [2] [13] [14]. More importantly, as students obtained materials before the classroom session, they have more opportunity to study and discuss the materials with peers.

Beside benefiting the students, the FC mode provides teachers with an opportunity to incorporate the learning material and video lecture as learning assistance to support individual student's learning in their homes [12]. A body of literature has suggested that the model facilitated students' independent learning as they have more opportunities to manage their learning time. Many teachers also believe that the FC enables personalised learning that may positively impact on the students' cognitive development [6], [13], [17].

\subsection{Video lecture}

The application of video lectures in the FC has been widely recognised to support the student learning experience [6], [17], [18], providing students with the opportunity, not only to learn independently, but also revisit lectures out of the class [15]. For example, if students do not understand the core content of material, then they can play a video to clarify the missed concept. Furthermore, students who understand the corematerial can also play the video to boost their competence. Indeed, the video lecture offers more opportunities for students to watch and review the lecture in a more convenient way of learning [19], [20].

In the current study, we recorded teachers' instructions during the FC to serve three main purposes:

- To support the students centred learning experiences in the FC

- To allow students to comprehend the core content of the subjects by reviewing them at home

- To provide the podcast explanation about the necessary exercises. Figure 1 details the steps of the video lecture development process: 


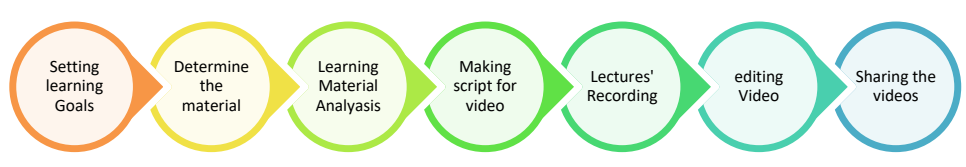

Fig. 1. Video lecture development process

In setting learning goals, the team determined the minimum competences that students were required to be achieve, then selected the learning material to be given to students. The learning material was assessed throughout the process by preparing entire aspects, such as teaching delivery, and media required, for excellent video lecture. After the preparation, a script was developed for the video lecture to guide the recording process, minimising potential errors during the recording. Two scripts were developed: an explanation lecture and student exercise video instruction. The explanation video lecture was concerned with the main-content of the subject, while the student exercises aimed to assist students to understand the necessary problems. The duration of the video explanations was approximately 45 minutes, with an average duration of 15 minutes per mathematics problem for the exercises video.

\subsection{Instructional delivery methods}

Instructional delivery method in this paper adapted the procedure of Solihat and Mulyono [21]. Flipped classroom provides an opportunity for teachers to implement and combine two learning models: learning in video lecture and face to face learning models. Face to face, sessions (F2F) aimed to:

- Allow teachers to explain material that cannot be understood

- Facilitate learning in groups of students

- Class discussion: F2F lasted 120 minutes and were conducted once a week.

In total, thirteen topics were discussed during thirteen F2F sessions, in which students were assigned into small groups of five to enable collaborative learning. Many studies have suggested that collaborative learning with peers helps students to be more active, enable them to exchange their understanding related to materials, as each student has a different level of understanding [22]. During the students' collaborative work, teachers acted as facilitators to control the group activities and to help clarify particular complex problems [20]. The entire F2F instructional class procedure followed the lesson plan as follows:

\section{Objective:}

- To help pre-service teachers understand concepts, and the basics of mathematical modelling.

- To enable pre-service teachers to complete modelling and mathematics materials.

- To help pre-service teachers develop and design mathematical problems related to modelling. 
Textbook: Varberg, D., Purcell, E. J., \& Steven, S. E. 2007. Calculus, 9th. New York: Pearson/Prentice Hall.

Time: Thirteen sessions, 120 minutes per procedure:

- Pre-presentation stage (25 minutes). Students discuss in groups FC that have been studied before the lecture, including preparing the results of group discussions related to materials, laptops, markers, presentation files and preparing the projector.

- Presentation stage (20 minutes). Students present the results of their discussions related to topics that have been studied before the lecture. The presentations were carried out in groups, which were randomly assigned by the teacher.

- Discussion phase (10 minutes). Students participate in question and answer sessions related to the presentation.

- Teacher feedback (25 minutes). The teacher provides feedback and clarification related to the presentation material and discussion.

- Exercise tasks (40 minutes). The teacher provides exercises related to the material to the whole group. Students are asked to discuss, perform the exercises given, and present the results of their work in front of the class.

- Teacher feedback (15 minutes). The teacher provides feedback on the presentation of the exercises that have been done and presented by the students.

In addition to F2F, virtual activities in FC were also conducted to facilitate student learning outside the classroom. According to Harrington [5], the percentage of virtual activities in F2F-C class sessions ranged between $20 \%$ and $80 \%$. In the context of this study, the goal was to use virtual classrooms to replace F2F sessions in the delivery of lecture material. Specifically, the virtual class aims to

- Provide students with independent learning through FC prepared by the teacher

- Help students to improve their understanding of modelling mathematics

- Provide learning assistance by providing explanations related to solving problems that are integrated with the reference book.

In practising the flipped classroom, video lectures were prepared to help teachers explain and re-explain materials from the textbook. Roux and Nagel (2018) stated that students were usually too lazy to read the book; videos provided the main material explanation so that students can learn the material before the class [4], with both subject material and exercise explanations generated in video lecture format. The subject material explanation was provided step by step, explaining the subject from the beginning until the end to support students to learn individually in their home [17], [19].

\section{Methodology}

\subsection{Reflective teaching}

Reflective teaching is considered an alternative to help promote teacher's professional development [24]-[26]. It provides teachers with a wonderful 
opportunity to see the fundamental principles and beliefs which highly affect their practice in the classroom. Reflection activity can be an effective tool [27], not only to describe the teacher profile, but also to improve the students' learning environment. The main purpose of reflective teaching is to investigate teacher practice more deeply in an attempt to understand comprehensively how to increase student learning [9]. Investigating teaching practice in the classroom, provides information regarding activities that need to be improved, as well as those aspects that can be kept, which can help to achieve more effective classroom practice in the future.

In conducting our reflective teaching practice, we employed several instruments such as self-observation, student journals and questionnaires. Similar instruments were apparent in previous reflective practice studies [28]-[30]. Self-observation can help to examine teaching practice through simple actions like taking notes when teachers are aware of a mistake. The reflection also needs to be supported by the results of student questionnaires [31], as a response to past experience and involves conscious withdrawal and experience examination as a basis for evaluation and decision making, as well as a source for planning and action [10]. Students' responses can be the greatest source for teaching evaluation to help improve teaching practice quality. It was anticipated that these various instruments of reflective teaching would support and motivate us to provide more effective teaching in future classroom practice.

\subsection{The participants}

Thirty-one pre-service teachers enrolled in modelling mathematics courses were involved in our flipped classroom practice, of which there were eight males and twentyfour females. Our observation before this study showed that they could operate basic computer applications, including the ability to operate videos on a computer, open files stored in a flash disc, make presentations with power point and operate multimedia applications. Also, they could operate internet search engines, correspond by email, upload and download applications and files from websites and do offline and online printing. In addition to these computer skills, they could make connections between smartphones and computers (also laptops), particularly transferring data from smartphones to computers or laptops.

\subsection{Data collection methods and the analysis}

Three data collection methods were employed to help reflect on the experience of teaching the flipped classroom, namely self-observation, student journals, and student questionnaires. According to Solihati and Mulyono [21], self-observation allows teachers to examine and observe their teaching practice so that they can continue to improve their learning activities. To implement self-observation, the teachers collected the information gathered from class discussions and student feedback during their learning out of the class in addition to student journals. Students were also asked to get involve in the survey related to teaching with flipped classroom. 
As suggested by Solihati and Mulyono [21], the data collected from self-observation and student journals were analysed using content analysis adopting Rayford's (2010) procedure. First, the observations and student journals were colour coded according to emerging themes, which were then collated to establish the pattern and to calculate the frequency. Finally, the frequency and code pattern led to the reflections and outline discussion sessions. The results of the student questionnaires were statistically analysed, calculating the mean (M) and standard deviation (SD).

\section{$4 \quad$ Findings and Discussion}

This section will present the findings obtained from critical reflection on FC teaching in mathematical modelling for pre-service teacher. The following themes is appeared from the reflection.

\subsection{Advantages of flipped classroom}

Flipped classroom helped students to comprehend the mathematic modelling lesson: The FC practice used video lectures purposely designed to support students' understanding of mathematical modelling. Student usually spent more than an hour to learn new material, however learning through video lecture allowed students to manage their own time. Some students watched the entire video explanation without stopping, while others stopped and started the video when they understood the explanation. In addition, some students repeated the video explanation according to their understanding. Data have shown us that students can easily hone their understanding through exercising problems, when students face difficulties, they can refer to the video explanation and exercises [5]. Before starting the face to face session, most students were familiar with the material that they were going to learn. The FC model not only allowed students to learn earlier in their home, but also facilitated students to improve their understanding about the subject.

This information indicated that the flipped classroom not only facilitated students to attain mathematical knowledge independently but also allowed students to improve their competence gradually through learning out of the class. The flipped classroom was also useful for teachers and students, as teachers could prepare and explain the video lecture in their home, while students can easily learn the material in their home. Although face to face contact can be diminished [32], some mathematical problems need direct communication between teachers and students. Nonetheless, this learning model has proven that the flipped classroom can support students' mathematical competence as well as students' learning outcomes.

The flipped classroom increased students' learning awareness: The flipped classroom encouraged students to have learning awareness, mainly because the student needed to determine when they started to learn the material or when they stopped learning. Although learning before class is challenging for students [26], some students reported that this learning model had gradually improved their learning motivation, although they were required to put in more effort before the class. In FC practice, 
students were encouraged to use the pause button when watching the video explanation and if they encountered any difficulties, they should take notes and record any problems corresponding to content lectures [23]. Bergmann and Sams (2012) stated that students who implement note taking typically come to class with some reasonable problems that teachers can assist them to overcome. Consequently, the FC model gave students an opportunity to realise their weaknesses, so that in the class meetings, they could ask questions. During interviews, students reported that "this learning model enforced me to set the particular time when to start learning", even though Xiu et al. (2018) stated that some students may resist adopting the FC model because it requires more effort on the students' part.

Flipped classroom supports a collaborative learning environment: The FC encouraged students to learn in a collaborative learning environment, with some students initiating small group discussions. The groups were designed to facilitate peer teaching activities among students. Indeed, most students watched the videos in small groups of three or four students, not alone but they encouraged their peers to learn together in a particular place. By learning together, they shared their understanding, as once a student understood the concept, they could help their friends to achieve the learning objective. This indicated that the FC supported students to learn collaboratively with their peers, so that when they encountered any difficulties, they posed questions to their peers without hesitation. This suggested that collaborative learning strengthened student communication skills, continuously helping students to grow into a productive group discussion. Although not all problems can be solved in a group discussion, students can record all difficulties and ask questions in class meetings [6]. Tague and Czocher (2016) reported that flipped classroom promoted students to work together, in class and out-of-class instruction, thereby continuously having a positive impact on students' learning [34]-[36].

\subsection{The challenges in applying flipped classroom}

There are several challenging aspects in the implementation of flipped classroom such as technical issues and it is time consuming as follows:

\section{Technical Issues}

Recording skills for flipped classroom: Recording skills are an issue when making video lecture. Although an appropriate camera was provided for recording the video explanations, making a good video requires recording skills. For example, during recording, the teacher did not remain in the same place, sometimes they needed to move to write on the whiteboard or she/he demonstrate a particular concept, but as the camera only recorded in one angle, it had to move according to the teacher's position, which disturbed the video explanation so that the video lecture did not produce good video images.

Video editing skills for the flipped classroom: Once the learning video is available, it is necessary to have the editing process skills and the video transfer process so that it is worth sharing. In this first case, we found it difficult to video edit and were required to familiarise ourselves with the video editing software. We required help to edit the videos so that each video took more than three hours to edit, which was time consuming 
and impacted on the FC preparation. On reflection, video editing was a vital process for FC preparation, so additional help was required so that we could focus on the teaching process.

Flipped classroom was time consuming during the preparation process: FC learning requires a lot of preparation, such as:

- The material to be delivered,

- Recording readiness for FC assistance,

- Exercises used to evaluate students' understanding, and

- Preparing assessment instruments during face-to-face meetings.

To prevent long recording times, teachers should prepare the recording readiness for FC assistance to help make effective video lectures. Teachers should also prepare the instruments to evaluate students' understanding as FC practice eliminates some faceto-face meetings. The instruments should ensure that students comprehend the given material, analyzing both students' strengthens and weaknesses regarding the material. The instruments to evaluate face-to-face meetings should facilitate students' activities both in and out of the classroom, evaluating students' learning activities to help identify any problems encountered by students. Students can reveal their problems privately or in front of the class. The complete preparation is required before the class begins, requiring commitment from the entire team for the success of FC activities.

\subsection{The impact of flipped classroom on students}

Student responses: Table 1 provides a summary of the student questionnaires. In general, the students agreed that the learning course content was easy to understand ( $\mathrm{M}$ $=4.56, \mathrm{SD}=0.70)$, that the course intellectually stimulating their interest in this subject $(\mathrm{M}=4.41, \mathrm{SD}=0.96)$ and the flipped classroom stimulated their interest in this subject $(\mathrm{M}=4.03, \mathrm{SD}=1.03)$.

Most students were very satisfied with the quality of the flipped classroom $(\mathrm{M}=$ $4.15, \mathrm{SD}=0.89$ ). Furthermore, the questionnaire results showed that most students greatly appreciated this flipped classroom activity $(\mathrm{M}=1.66, \mathrm{SD}=0.69)$ and they intend to use the system for learning in familiar authentic environments in the future $(\mathrm{M}=4.21, \mathrm{SD}=1.04)$. For example, when students encountered some difficulties, they recorded the problem on paper.

At the end of every session, the learning activity was evaluated in three different aspects: learning material, video lecture, and classroom activity. First, regarding learning materials, $40 \%$ of student reported that they were very good, $25 \%$ good, $20 \%$ excellent, and $15 \%$ of students thought they needed improvement. Secondly, most students considered the video lecture as very good and excellent for supporting flipped classroom, although the video quality needed to improve. Lastly, most students thought that the classroom activities were good.

In formatting this reflection, we also asked some group representatives to comment on our teaching performance. One student commented "I am very happy in this learning model because I can learn the material prior to meeting in the class", suggesting that 
the FC model motivated him to learn at home and that it has continuously had a positive impact on students' learning [34]-[36].

Table 1. Students responses regarding learning experiences using flipped classroom

\begin{tabular}{|c|c|c|c|}
\hline \# & Item & Mean & SD \\
\hline \multicolumn{4}{|c|}{ Students response in Learning Material } \\
\hline 1 & $\begin{array}{l}\text { I benefited a great deal from the course content and understood the subject material } \\
\text { of this course }\end{array}$ & 4.56 & 0.70 \\
\hline 2 & I have found the course intellectually challenging and stimulating & 4.41 & 0.96 \\
\hline 3 & My interest in the subject has increased as a consequence of this flipped classroom & 4.03 & 1.03 \\
\hline 4 & I believe I have achieved the learning outcomes of the course & 4.18 & 1.00 \\
\hline 5 & The assignments helped me attain the learning outcomes of the course & 4.06 & 0.89 \\
\hline 6 & The course video lecture helped me attain the learning outcomes & 4.41 & 0.99 \\
\hline 7 & Using the system improves my learning performance & 4.26 & 0.83 \\
\hline \multicolumn{4}{|c|}{ Overage of video lecture in flipped classroom } \\
\hline 8 & Using the flipped classroom improves the quality of my learning & 4.15 & 0.89 \\
\hline 9 & Using the system helps me to accomplish learning tasks more quickly & 4.62 & 0.70 \\
\hline 10 & Using the flipped classroom increases my productivity & 4.24 & 0.99 \\
\hline 11 & Using the flipped classroom enhances my effectiveness on the learning & 4.00 & 1.04 \\
\hline 12 & Using the flipped classroom improves my learning performance & 4.26 & 0.90 \\
\hline 13 & Using the flipped classroom improves my modelling performances & 4.03 & 0.97 \\
\hline \multicolumn{4}{|c|}{ Overage of perceived classroom activity } \\
\hline 14 & I think using the system for learning is more interesting than using a textbook & 4.00 & 0.89 \\
\hline 15 & I like to practice my skills with the system in real-life situations & 4.32 & 0.91 \\
\hline 16 & I feel more free and relaxed during my learning with the flipped classroom activity & 4.12 & 1.07 \\
\hline 17 & $\begin{array}{l}\text { I think I learned more by using the flipped classroom than by using a traditional } \\
\text { learning model }\end{array}$ & 4.03 & 0.90 \\
\hline 18 & Using the flipped classroom activity can increase my learning motivation & 4.09 & 0.93 \\
\hline 19 & $\begin{array}{l}\text { If I had to give a grade to my learning experience with the system, I would give it } \\
\text { high score }\end{array}$ & 4.41 & 0.82 \\
\hline 20 & I feel happy to use this flipped classroom learning modelling in the future & 4.21 & 1.04 \\
\hline
\end{tabular}

Note: Mathematical Modelling.

\section{$5 \quad$ Conclusion and Implications}

The main purpose of this research was to understand the effectiveness of the flipped classroom via teaching reflection. The reflection on the implementation of the flipped classroom indicated that the major problems were technical problems that required expert assistance in the successful implementation of the flipped classroom. The flipped classroom was a very different experience for students as they had to study first at home. Nonetheless, it encouraged collaborative learning and the creation of a peer teaching environment. Self-study before learning in class is challenging and requires effort on the part of the students. Diligent students were highly motivated and students experiencing difficulties requiring peer assistance in understanding encouraged the creation of peer teaching among students. 


\section{References}

[1] L. Martínez and P. Garaizar, 'Learning physics down a slide: A set of experiments to measure reality through smartphone sensors', Interact. J. Interact. Mob. Technol., vol. 8, no. 3, pp. 40-43, 2014. https://doi.org/10.3991/ijim.v8i3.3873

[2] H. Ng and S. S. Baharom, 'An analysis on adult learners' satisfaction in online education programmes', Int. J. Interact. Mob. Technol., vol. 12, no. 7, pp. 70-85, 2018. https://doi.org/10.3991/ijim.v12i7.9665

[3] T. Muir and V. Geiger, 'The affordances of using a flipped classroom approach in the teaching of mathematics: a case study of a grade 10 mathematics class', Math. Educ. Res. J., vol. 28, no. 1, pp. 149-171, 2016. https://doi.org/10.1007/s13394-015-0165-8

[4] C. White et al., 'Challenges to Engaging Medical Students in a Flipped Classroom Model', Med. Sci. Educ., vol. 25, no. 3, pp. 219-222, 2015. https://doi.org/10.1007/s40670-015$\underline{0125-7}$

[5] N. H. Wasserman, C. Quint, S. A. Norris, and T. Carr, 'Exploring Flipped Classroom Instruction in Calculus III', Int. J. Sci. Math. Educ., vol. 15, no. 3, pp. 545-568, 2017. https://doi.org/10.1007/s10763-015-9704-8

[6] J. Bergmann and A. Sams, Flip Your Classroom Reach Every Student in Every Class Every Day. 2012.

[7] C. Kreber, 'Reflection on teaching and the scholarship of teaching: Focus on science instructors', High. Educ., vol. 50, no. 2, pp. 323-359, 2005. https://doi.org/10.1007/s10734004-6360-2

[8] J. I. Kitsuse, 'Talk about teaching: Reflections on the problem of teaching evaluation', Am. Sociol., vol. 40, no. 1-2 SPEC. ISS., pp. 3-14, 2009.

[9] K. Driscoll, 'Improving the Effectiveness of Mathematics Teaching through Active Reflection', in Proceedings of the 38th annual conference of the Mathematics Education Research Group of Australasia, 2015, pp. 205-212.

[10] C. R. Lotter and C. Miller, 'Improving Inquiry Teaching through Reflection on Practice', Res. Sci. Educ., vol. 47, no. 4, pp. 913-942, 2017. https://doi.org/10.1007/s11165-016-9533$\mathrm{y}$

[11] J. Ferrer-Torregrosa, M. Á. Jiménez-Rodríguez, J. Torralba-Estelles, F. Garzón-Farinós, M. Pérez-Bermejo, and N. Fernández-Ehrling, 'Distance learning ects and flipped classroom in the anatomy learning: Comparative study of the use of augmented reality, video and notes', BMC Med. Educ., vol. 16, no. 1, pp. 1-9, 2016. https://doi.org/10.1186/s12909-016-0757-3

[12] T. Wang, 'Overcoming barriers to "flip": building teacher's capacity for the adoption of flipped classroom in Hong Kong secondary schools', Res. Pract. Technol. Enhanc. Learn., vol. 12, no. 1, p. 6, 2017. https://doi.org/10.1186/s41039-017-0047-7

[13] K. Lee and Y. Lai, 'Facilitating higher-order thinking with the flipped classroom model: a student teacher's experience in a Hong Kong secondary school', Res. Pract. Technol. Enhanc. Learn., vol. 12, no. 1, p. 8, 2017. https://doi.org/10.1186/s41039-017-0048-6

[14] S. M. Chan, J. Y. Tse, and P. H. Yu, 'The flipped classroom in an undergraduate nutritional science course: A pilot study', Springerplus, vol. 4, no. Suppl 2, p. P3, 2015.

[15] B. J. Beatty, Z. Merchant, and M. Albert, 'Analysis of Student Use of Video in a Flipped Classroom', TechTrends, no. Karnad 2013, pp. 1-10, 2017.

[16] M. Canellas and J. L. Kendall, 'The Flipped Classroom: Addressing the Ultrasound Curriculum Gap in Undergraduate Medical Education', Med. Sci. Educ., vol. 28, no. 2, pp. 303-307, 2018. https://doi.org/10.1007/s40670-018-0539-0 
[17] Y. Xiu, M. E. Moore, P. Thompson, and D. P. French, 'Student Perceptions of LectureCapture Video to Facilitate Learning in a Flipped Classroom', TechTrends, pp. 1-7, 2018. https://doi.org/10.1007/s11528-018-0293-6

[18] Q. Zhang and F. Wu, 'Study on Teacher - Student Interaction in Flipped Classroom Based on Video Annotation Learning Platform', in Lecture Notes in Educational Technology, Singapore: Springer, Singapore, 2016, pp. 257-261. https://doi.org/10.1007/978-981-287868-7 29

[19] G.-J. Hwang, C.-L. Lai, and S.-Y. Wang, 'Seamless flipped learning: a mobile technologyenhanced flipped classroom with effective learning strategies', J. Comput. Educ., vol. 2, no. 4, pp. 449-473, 2015. https://doi.org/10.1007/s40692-015-0043-0

[20] E. K. Lew, 'Creating a contemporary clerkship curriculum: the flipped classroom model in emergency medicine', Int. J. Emerg. Med., vol. 9, no. 1, 2016. https://doi.org/10. 1186/s12245-016-0123-6

[21] N. (Universitas M. P. D. H. Solihati and H. (Universitas M. P. D. H. Mulyono, 'A Hybrid Classroom Instruction in Second Language Teacher Education ( SLTE ): A Critical Reflection of Teacher Educators', Int. J. Emerg. Technol. Learn., vol. 12, no. 5, pp. 169180, 2017. https://doi.org/10.3991/ijet.v12i05.6989

[22] C. O. Anhalt and R. Cortez, 'Developing understanding of mathematical modeling in secondary teacher preparation', J. Math. Teach. Educ., vol. 19, no. 6, 2016. https://doi.org/10.1007/s10857-015-9309-8

[23] I. le Roux and L. Nagel, 'Seeking the best blend for deep learning in a flipped classroom viewing student perceptions through the Community of Inquiry lens', Int. J. Educ. Technol. High. Educ., vol. 15, no. 1, 2018.

[24] M. Kim, J. Lavonen, K. Juuti, J. Holbrook, and M. Rannikmäe, 'Teacher's reflection of inquiry teaching in finland before and during an in-service program: Examination by a progress model of collaborative reflection', Int. J. Sci. Math. Educ., vol. 11, no. 2, pp. 359383, 2013. https://doi.org/10.1007/s10763-012-9341-4

[25] W. Liu, 'An analysis and reflection on effective teaching', Front. Educ. China, vol. 3, no. 1, pp. 149-161, 2008. https://doi.org/10.1007/s11516-0008-0010-x

[26] B. H. W. Yung, S. L. Wong, M. W. Cheng, C. S. Hui, and D. Hodson, 'Tracking pre-service teachers' changing conceptions of good science teaching: The role of progressive reflection with the same video', Res. Sci. Educ., vol. 37, no. 3, pp. 239-259, 2007. https://doi.org/10.10 07/s11165-006-9024-7

[27] C. R. Rayford, 'Reflective practice : The teacher in the mirror', Graduate College University of Nevada, Las Vegas, 2010.

[28] N. Solihati and H. Mulyono, 'A Hybrid classroom instruction in second language teacher education (SLTE): A critical reflection of teacher educators', Int. J. Emerg. Technol. Learn., vol. 12, no. 5, pp. 169-180, 2017. https://doi.org/10.3991/ijet.v12i05.6989

[29] A. Hikmat and H. Mulyono, 'Smartphone use and multitasking behaviour in a teacher education program (TEP)', Int. J. Interact. Mob. Technol., vol. 12, no. 2, pp. 4-14, 2018. https://doi.org/10.3991/ijim.v12i2.7345

[30] H. Dianawati and H. Mulyono, 'Facilitating students' creativity in an EFL writing classroom: Voices from the field', ARGENTINIAN J. Appl. Linguist., vol. 4, no. 2, pp. 3947, 2016.

[31] H. Suharna, 'Berpikir Reflektif (Reflective Thinking) Siswa SD Berkemampuan Matematika Tinggi Dalam Pemahaman Masalah Pecahan', Semin. Mat. dan Pendidik. Mat., no. November, pp. 377-386, 2012. 
[32] R. Ørngreen, 'Reflections on Design-Based Research In Online Educational and Competence Development Projects', in IFIP Advances in Information and Communication Technology, vol. 468, 2015, pp. 20-38.

[33] J. Tague and J. Czocher, 'A Theoretical Approach to Ensuring Instructional and Curricular Coherence in the Flipped Classroom Model of a Differential Equations Course', Int. J. Res. Undergrad. Math. Educ., vol. 2, no. 2, pp. 223-245, 2016. https://doi.org/10.1007/s40753016-0028-Z

[34] J. Albert, M. R. Blanchard, J. L. Albert, M. R. Blanchard, S. J. Carrier, and G. E. Gardner, 'Supporting Teachers' Technology Integration: A Descriptive Analysis of Social and Teaching Presence in Technical Support Sessions Supporting Teachers ' Technology Integration: A Descriptive Analysis of Social and Teaching Presence in Technical Support ', no. July 2014, 2015.

[35] C. Demetry, "Work in Progress - An Innovation Merging "Classroom Flip " and TeamBased Learning', in The 40th ASEE/IEEE frontiers in education conference, 2010, pp. 2627.

[36] T. Long, J. Cummins, and M. Waugh, 'Use of the flipped classroom instructional model in higher education: instructors' perspectives', J. Comput. High. Educ., vol. 29, no. 2, pp. 179200, 2017. https://doi.org/10.1007/s12528-016-9119-8

\section{$7 \quad$ Authors}

Khoerul Umam is a lecturer at Faculty of Teacher Training and Pedagogy, Universitas Muhammadiyah Prof. Dr Hamka (UHAMKA). He is a Ph.D candidate at Universitas Negeri Malang. His research interests include mathematics teaching, ICT in classroom.

Toto Nusantara is a professor at Faculty Science, and Mathematics, Universitas Negeri Malang. His research interests include mathematics education, analysis, mathematical modeling.

I Nengah Parta is an associate professor at Faculty Science, and Mathematics, University Negeri Malang. His research interests include curriculum development, qualitative in mathematics education, and mathematical modeling.

Erry Hidayanto is an associate professor at Faculty Science, and Mathematics, Universitas Negeri Malang. His research interests include curriculum development, technology in mathematics teaching, and flipped classroom.

Herri Mulyono is a senior lecturer at Faculty of Teacher Training and Pedagogy, Universitas Muhammadiyah Prof. Dr Hamka (UHAMKA). He obtained his Ph.D in University of York. His research interests include the use of technology for foreign language learning.

Article submitted 2018-11-17. Resubmitted 2019-01-27. Final acceptance 2019-01-29. Final version published as submitted by the authors. 